\title{
Devolution and Governance Conflicts in Africa: Kenyan Scenario
}

\author{
Thomas Otieno Juma ${ }^{1}$, Jacob Kipkemboi Rotich ${ }^{2}$, and Prof. Leonard Simiyu Mulongo ${ }^{2}(\mathrm{PhD})$ \\ 1. Moi University School of Arts and Social Sciences; Department of History, Political Science, and \\ Public Administration; P.O. Box 3900- 30100, Eldoret- Kenya. \\ 2. Moi University; School of Human Resource Development; Department of Human Resource \& \\ Development Studies; P.O. Box 3900- 30100, Eldoret- Kenya. \\ Email: *thomasotienojuma@yahoo.com/richardorotich@gmail.com/lmulongo@yahoo.com
}

\begin{abstract}
The interests on devolved system of government have increased over time in Africa. This paper looks at devolution and governance conflicts in Africa. The paper makes an attempt in assessing the likely conflicts from this system and possibly so their mitigations with the Kenyan scenario. The study applies the underlined objectives in achieving its goals. Ultimately, the paper will attempt to answer questions such as; what is devolution? Why devolution? What is the rationale of devolution? What are the likely conflicts inherent in devolution and governance in Africa from the global experience? What are the mitigations available and its prospects and challenges? Confusions linger as to whether devolution is decentralization or federalism. In tackling the objectives, this study tries to make clarity to these dilemmas.
\end{abstract}

Key words: Devolution/ Decentralization/ Conflicts/ Governance

\section{Introduction and Background}

The context of devolution being subject of this paper is one of the many available. Devolution can both exist at within the state levels or under supranationalism context. The study looks at the former where devolution is exercised within the state. It is important however to pick certain attributes of this system from the supranationalism context. Memorandum by the Scottish Executive reveals that the profound impact of the European Union (EU) on policy-making in the UK has been widely acknowledged. The devolved institutions are no exception to that. Many of the functions devolved in Scotland, Wales or Northern Ireland are heavily affected by the EU - notably agriculture and fisheries, but also the environment, economic development.

Lebrecht, Finnie, Jones, and Small (2002) notes a similar difficulty arises in relation to modulation. Modulation is the term used for money paid to farmers not by way of subsidy but to support rural development more generally, in accordance with rural development plans. Separate rural development plans exist for England, Scotland, Wales and Northern Ireland, and each seeks to achieve rural development in different ways. However, EU law only permits a member state to apply a single rate of modulation (that is, the amount of money diverted to activities under the rural development plans). The devolved administrations cannot in fact decide to adopt their own rates of modulation, although the power to fix the rate is in law devolved. This macro-level is as well good for analysis of the micro-level perspective.

In this supra- arrangement, a lecture to Birmingham University finds that the Member States of the European Union, regional governments are increasingly finding new opportunities to participate in policy-making and implementation. In part this reflects the changing institutional structure of the EU itself, but it also reflects the changing nature of the relationship between the nation-state and its constituent parts. The form of intergovernmental relations between actors is evolving, not least in response to changing ideas on what constitutes 'good governance' (www.birmingham.ac.uk ). Due to devolution, there are bound to be institutional restructuring among constituent parts of a bigger unit yet opportunities are immense.

Systems that have been used in governance by many developing countries have tended to follow inheritance from the then colonizers. To some degree, they have been harnessing conflicts because of their incompatibilities with aspirations of the locals. Talbott and Lynch (1995) point the colonial administration had carried out deconcentration without or with devolution within very narrow limits. Some countries such as Thailand and Nepal were not under colonial rules but they have histories of centralization not much different from the colonial countries. In the region, however, there are some other countries which had a long history with traditional authority enjoyed by the decentralized units such as Papua New Guinea where 90-97\% of the land resources is owned by groups of families although used by individual households. Hye, (1985) observation is that in the postcolonial period, a general feature valid for the countries with centralized administration was to promote decentralization in the 1950s and early 1960s, waning of interest in it in the late 1960s and renewed interest from early 1970 onwards in some of them.

In these Asian cases, the degree of interest to deconcentration was the only important element. The other important elements namely the development of devolution had been very slow and disappointing. In most countries, notably there has been hardly any structural change to the administrative organization so that within a short period the deconcentrated units became more cosmetic than substantial. 
Accordingly, Kauzya (2007) continues and asserts that in terms of Public administration, historically African countries have experienced fused, personalized and at best highly centralized governance systems and practices. In pre-colonial times kings or traditional leaders represented basically all authority. During the colonial and immediate post-colonial periods governance was structured and practiced in a highly centralized manner. During military dictatorships that in many countries replaced the immediate post-colonial governments governance was practically personalized. The search for inclusive, involving, and participatory governance has taken the path of decentralization. Political and administrative reforms that have been going on in many countries in Africa, especially since the 1990s, have sought to break with the past through decentralization of powers to lower local governments.

Ndegwa (2002) in the table below shows the extent to which different African countries have decentralized their governance. The term decentralization embodies several concepts including devolution, deconcentration, delegation and delocalization. In many instances a decentralization policy that promises success will most likely include dozes of each of these. It might be interesting to find out by another study if the ten most decentralized states are experiencing better governance than other states in Africa.

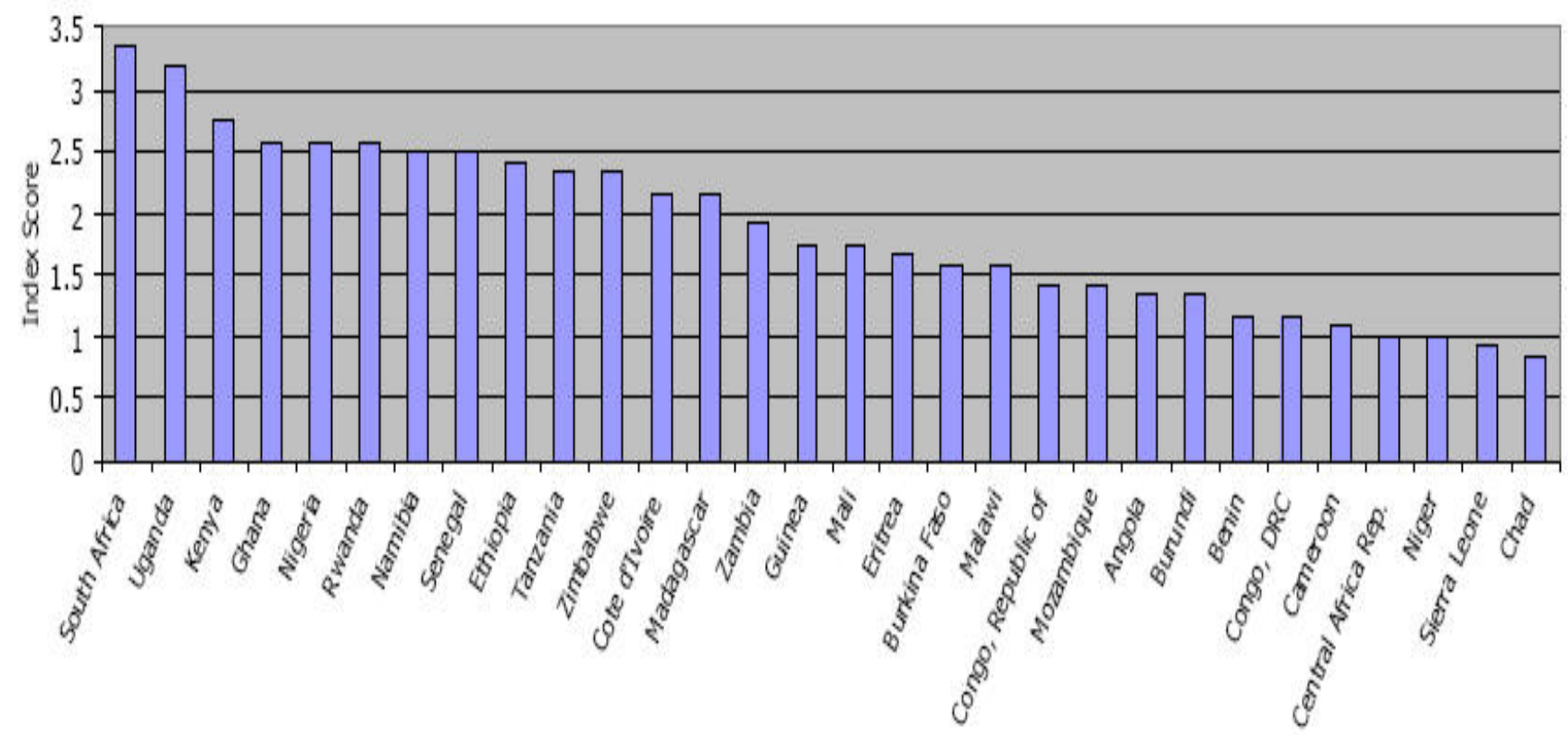

Each country should focus their movement to devolution/ or decentralization to their unique contexts. According to South African White Paper on Decentralization (1998), a logical argument is being raised as to why enter into decentralization. It suggests that in Uganda decentralization was born from the logic of searching for support for the guerrilla war and introducing grass-roots participatory democracy, in South Africa it was an offspring of the struggle to dismantle the segregating local administration system of apartheid. The process is different from the one in Uganda described above. In fact the debates on and publicity of the process of abolishing Apartheid at national level in a way masked what was going on at local level to introduce a local government system that would correct the socio-politico-economic injustices and segregation that obtained through apartheid. Although Apartheid was abolished during the first half of the 1990s, it left a permanent mark on the local government system in the country. For this reason a complete understanding of the process of post apartheid devolution is only possible when one grasps the history of human settlements and the role local governments played in establishing and sustaining separation, segregation, and inequality at local level. For this reason the authors of this paper think the same should form Kenya's journey to this system which has begun. Differences are wide though similarities are bound to exist in several ways.

To this, Kobia and Bagaka (2013) points, in August 2010, Kenyans promulgated a new constitution which, among other things, devolved political, fiscal and administrative powers from the national government to 47 counties. Unlike other countries where the devolution process of the three powers has been sequentially attained, in Kenya the experience has been a 'big bang' where the three types of decentralisation were achieved at once with the ratification of the constitution. Further, the constitution requires 'each level of government to perform its functions and powers in a manner that respects the functional and institutional integrity of the government at the other level' (Art. 189, Kenya's constitution). Kenya's historical experiences informed the inclusion of these constitutional clauses specifically to protect counties from having their powers usurped by the national government, as previously happened under the old constitutional order. 
While castigating centralized systems with reference to Zimbabwe, Moyo (2014) further states, it is quite clear the current system of a highly-centralised state as we have in Zimbabwe has promoted autocracy, inefficiency, corruption and exclusion of people from full participation in how they are governed. Devolution can certainly help to address some of these problems. So claims by Mugabe and Chombo that devolution divides people are not just misleading but also false. There are many examples of devolved states in Africa and elsewhere in the world which are working well. In fact, devolution, instead of dividing people, promotes equitable distribution of resources and above all national cohesion. At the core of any government is the ability to deliver a sound economy and sound governance to its citizens and that can only be achieved if there is fairness in the distribution of the resources. What is happening now does not at all reflect fairness in the distribution of the national cake.

Concentration by many on devolution without looking at the historical background on why Kenya chose devolution like the rest of other countries in the developing world might cause the its future derailed. The why the country entered into it should guide the how it should be handled or else the country will leap several years back into its search for a viable system of governance yet the constitution 2010 seems to have brightened much hope.

\section{Statement of the Problem}

Devolution system of governance in Kenya was a very well received and desired system as a way of departure from the centrality and "former Provincial Administration", dubbed ambitious system of governance. Though at its very rudimentary stages, it can be too early to judge its successes and failures but the prospects can be anchored on the proceedings of its ongoing implementations. However, it is unclear whether the conflicts it is facing are due to its infancy or because of misunderstandings of its expectations by the stakeholders concerned in its implementation.

\section{Significance of the Study}

The significance of this research is that it will help national government policy makers, county government policy makers, politicians, citizens, the business community, other non-state actors, and academia in understanding their role in harnessing proper functioning of devolution and mitigating conflicts as they occur.

\section{Methodology}

The study opted to use a qualitative design as well as document analysis to come up with its body of reliable knowledge in this topic of study.

\section{Objectives}

This study relied on the following three objectives in its attempt to answer the devolution and governance related conflicts in Africa with Kenya as a case. The objectives included;

- Identifying devolution and governance conflicts in Africa, Kenyan scenario,

- Finding mitigations to devolution and governance conflicts in Africa, Kenyan scenario, and

- Highlighting Prospects and challenges to devolution and governance conflicts in Africa, Kenyan scenario.

\subsection{Devolution and Governance Conflicts in Africa, the Kenyan Scenario}

Before embarking on the local scene, such conflicts have been witnessed elsewhere and from this, important lessons can be borrowed. It was reported by Colombage (2014), the Sri Lankan government has announced that they would not fully devolve police and land powers to provincial governments as per the country's constitution, despite growing pressure from India's new government. This necessitated the Indian government to sponsor a resolution on Sri Lanka at the United Nations. She demanded a referendum to be held among the Sri Lankan Tamils for the creation of a separate state for the minority community within Sri Lanka.

Kauzya (2007) makes a caveat to the devolution debate thus; "The mere fact of opting for decentralization shall not by itself ensure that the population effectively participates in its development which is the ultimate goal of a good policy of decentralization and good governance. It is important to set up mechanisms reassuring the participation of the population...." This poignant warning implies that however good the system may be, it is bound to have setbacks.

"In fact [devolution] could even result in entrenching disparities if the right policies are not implemented," the report says. "A rushed transition could set up counties to fail by giving them responsibilities before they have the capacity to carry them out." How should the redistribution be implemented? Kenya's counties start from very different positions, but experts at the World Bank say the immediate priority should be preserving existing service delivery - any drastic move to redistribute resources away from affluent towards destitute counties could result at best in severe fiscal stress, or even the collapse of essential service delivery. Experts warned it will take time for Kenyans to understand how the new government will work, and without skillful management both at national and county levels, the central promise of the country's new Constitution could end up being stillborn, notes Mungai (2013).

Political decentralization can be understood to refer to either or both of the following: (i)Transferring the power of selecting political leadership and representatives from central governments to local governments, and (ii) 
Transferring the power and authority for making socio-politico-economic decisions from central governments to local governments and communities: Understanding political decentralization only in the first sense would be limiting the meaning of "political" to the choice of political leadership through elections. Therefore the promotion of political decentralization in this sense would entail only putting in place structural arrangements that would facilitate local people to exercise their voting power with limited hindrance or intervention from central government. Here political decentralization would be referring to only electoral decentralization and participation would be understood only in terms of elections. On the other hand, promoting political decentralization in the second sense, would entail putting in place structural arrangements and practices that would empower and facilitate local governments and communities to exercise not only the voting power in the choice of their local leadership and representatives but also to have strong influence in the making, implementation, monitoring, and evaluation of decisions that concern their socio-politico economic wellbeing and to constantly demand accountability from their local leadership Kauzya (2003).

There is need to define what devolution is and what it is not. Devolution simply means a legal granting of powers from central government to lower levels of government such as provincial, district or municipal tiers. It is a political and financial issue as it involves election of local representatives by local people and giving those lower levels of government a budget that is normally administered by central government. Federalism involves the sharing of power to govern between the national and state or provincial governments as defined by the constitution. Quite clearly, there is a world of a difference between devolution and federalism (Moyo, 2014).

The rationale behind devolution is guided by different historical dispensations unique to every country. In the three countries (Uganda, Rwanda, and South Africa) decentralization policy documents can be found. Essentially decentralization in the three countries was promoted in response to the political and economic problems in their history. In South Africa, emphasis was promoting local governments was aimed at "rebuilding local communities and environments, as the basis for a democratic, integrated, prosperous and truly non-racial society", following the trauma of apartheid in the country; In Rwanda decentralization was to "provide a structural arrangement for government and the people of Rwanda to fight poverty at close range, and to enhance their reconciliation via the empowerment of local populations", following the trauma of the genocide of 1994; while in Uganda decentralization is "a democratic reform, which seeks to transfer political, administrative, financial and planning authority from central government to local government councils and to promote popular participation, empower local people to make their own decisions and enhance accountability and responsibility" (Kauzya, 2007; ROS, 1998; GOR, 2001; GOU, 1994). The Kenyan experience is also different based on her socio-eco-political dynamics which might not be far from these African countries.

Factors that have accelerated decentralization which is used interchangeably to devolution at certain times include;

1. State coercion,

2. Political Democratization: Usually through popular elections at different levels,

3. Peoples' power and popular pressure

4. Traditional historical understanding that it existed in the past to many developing countries.

5. A combination of above factors noticed in different countries.

The Kenyan scenario was probably very ambitious to have trusted an implementation of a new system to a winning government singly. From the Pakistan experience, involvement could have been key. This doesn't matter which coalition came to power. Whether CORD or the reigning Jubilee, the prospects would be similar. Asian Report (2014) identifies an imminent friction growing between various levels of government, especially since the military transferred power, at least formally, to the central and provincial governments that were formed after the 2002 elections. These tensions are partly the result of the manner in which the devolution plan was devised and implemented in the absence of elected officials and against the strong opposition of the major political parties, civil society and media. Devolution, in fact, has proved little more than a cover for further centralized control over the lower levels of government. Despite the rhetoric from Islamabad of empowerment, local governments have only nominal powers.

The authors underscore an observation in Kauzya (2007) the experience of Uganda, Rwanda, and South Africa also illustrate that whether decentralization is demanded as in South Africa, engineered from the top through consultations and pilot programs as in Uganda, or directly driven from the top as in Rwanda, the process of agreeing the exercise of shared power and authority should not be taken for granted. Whichever approach applied, support for decentralization comes through patient and sustained negotiation and other sustainable means for conflicts to be mitigated. 
Conflicts in devolution and governance arise out of the causes of such conflicts which are not limited to the few mentioned below;

- Unilateral unconstitutional declarations based on power preservation tendency (Colombage, 2014),

- Embracing the system without proper mechanisms of participation and goodwill to participations,

- Rushed transitions coupled with budgetary- fiscal stress,

- Failure to set up realistic structural arrangements and practices for empowerment of devolution,

- Failure to fall back to understanding a country's historical linkage to the new systems e.g. devolution,

- Political exclusion tendencies. The Kenyan devolution is now almost at the mercy of people's representatives with no proper forums for the masses to carry out watchdog like the ujamaa policy frameworks of Tanzania. This in the end builds elitism from the local level upwards.

- Unclear constitutional articles, enforcing acts and institutions

There appears to be reluctance by select national officials and bureaucracies to give up certain functions to the county governments. Key among these is the management of urban and rural roads and rural electrification projects. Whereas the national officials argue that there is limited capacity to handle these functions at the county level, the county leaders accuse the national officials of crafting a plot to deny them essential resources to develop their counties and further accuse them of greed (Daily Nation, 2013; Kobia and Bogaka, 2013).

\subsubsection{Conceptualizing Devolution Conflict}

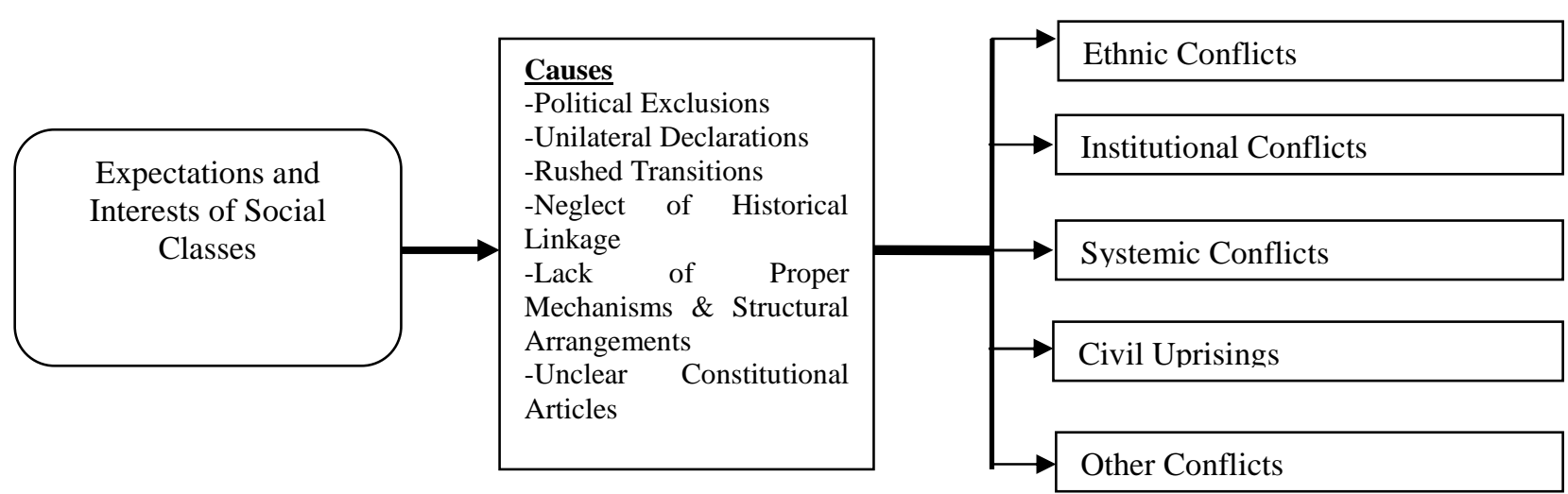

Figure 1. Authors' Conflict Model: A Simplified Model of Homer-Dixon in Deudney and Mathews (Eds) 1999.

From the foregoing conceptual frame, one would find that the expectations and needs of various social classes both at the national and county administrative units will interact and their results become what is in the box of causes which breeds the repercussions as the conflicts enumerated in the extreme end as ethnic conflicts, institutional, systemic, civil uprisings, e.t.c.

\subsection{Mitigations to Devolution and Governance Conflicts in Africa}

This section deals with how African countries have attempted to mitigate the conflicts occasioned by the quest for absolute devolution and governance through legal and constitutional frameworks, political and socioeconomic measures. Such attempts have been highlighted in the discussion below.

In this attempt the authors have narrowed to the situation in Kenya majorly looking at the Constitutional and legal framework.

The Constitution of Kenya, 2010, was adopted by sixty seven percent (67\%) of Kenyans in a national referendum on August 05, 2010, thereafter, promulgated on August 27, 2010. Thus the CK2010 became the supreme basic law replacing the nearly fifty year old Constitution of Kenya, 1963 (CK1963). The latter was enacted by the British House of Commons and issued as the Kenya Independence Order - in - Council of 1963. The concepts and principles of democratic governance in CK 2010 expressly provide for an unfettered sovereignty of the people as the arch-stone of government. Hence, the unequivocal right of the people to participate in and oversight the government, traverses the entire Constitution. Embedded, therein and of no less significance, are the objects and principles of devolved government. Devolution is principally meant to take away and re-distribute/share out the power to plan, legislate, budget and make policies for governing from an erstwhile highly centralized national executive and legislature to forty-seven county executives and assemblies. Constitutionalism as a mitigating factor to devolution and governance conflicts in Kenya has several dimensions some of which are highlighted below: 
There are at least four reasons why the 2010 constitution has enjoyed tremendous support in Kenya and beyond. First, the 2010 Constitution introduces far reaching changes to Kenya's system of governance.

It creates a decentralized (or "devolved?") system of government characterized by two levels of government, that is, the national government and the county governments. It should be noted that the centralized system of government is largely blamed for promoting and sustaining bad governance in Kenya. Ghai (2011) notes that:

"There was wide scale perception, which statistics support, that the centralised state has, for the last 50 years, singularly failed to promote economic and political development, and that only a few areas and a small elite had benefited from the policies of the government."

Second, the Constitution seeks to fundamentally restructure the core institutions of governance. In this regard, the Executive, Parliament and the judiciary are to be fundamentally restructured and reformed. For instance, the Executive is to be restructured by reinforced checks and balances from other institutions. The imperial presidency is to be restructured. Kennedy and Bieniek (2010) have remarked that:

"Although there will still be a strong Executive, the new reforms will significantly limit its power vis-à-vis the legislature and judiciary.

Third, the 2010 Constitution seeks to protect and promote the rights of its citizens in a more elaborate manner. The Constitution in this regard introduces an extensive, elaborate and liberal Bill of Rights that seeks to protect and promote social, economic and political rights of Kenyans. The protection of socio-economic rights (also known as second generation rights) like the right to accessible and adequate housing, the right to clean and safe water, social security, emergency medical treatment, to be free from hunger, and to have adequate food, among others, is an important addition by the 2010 Constitution.

Fourth, the 2010 Constitution introduces national values and principles of governance and further devotes a chapter on leadership and integrity. Absence of an adequate and enforceable code of ethics and normative standards for the public service has, since independence, created a public service weighed down by problems like rent seeking, corruption, poor governance, mismanagement of resources, tribalism, criminal conduct and impunity, among others.

The 2010 Constitution further seeks to deal with the problem of marginalization, the complex land question, and issues affecting nationality and citizenship, among others.

According to Sihanya (2011), the Kenyan constitution has rightly been lauded as a significantly progressive document that provides an elaborate framework for restructuring the state, and entrenching constitutional government as well as reconstructing or restructuring the state in Kenya. However, the most important process of restructuring the state in this sense is constitutional implementation. Constitutional implementation can be understood in two senses: first, the day-to-day process of fidelity to the text as well as principles that are legitimately derivable from the constitution by all organs involved in the governance process; and second, operationalization of the Constitution 2010 during the transition period immediately after promulgation of that constitution.

The constitutional implementation process in Kenya so far focuses on the second sense, and differs from the first meaning in a number of significant ways. First, constitutional implementation entails an initial, original, often rigorous debate on constitutional meaning or interpretation, relying on the constitutional text, structure, history and legal theory. Second, the framework for constitutional implementation is specifically provided for separately in the Constitution. Third, there is a specific, elaborate and limited timetable or timeframe for constitutional implementation. Fourth, specific sui generis (or special) constitutional organs are assigned the constitutional role of implementing the text. Fifth, specific legislation are outlined by the Constitution for enactment to implement specific constitutional provisions. And lastly, the Constitution provides for sanctions for failure to implement its provisions.

Some of the enabling legislations enacted by the parliament of Kenya that have a direct bearing on the implementation of devolution include:

- Urban Areas and Cities Act, No. 13 of 2011

- Commission on Revenue Allocation Act, No. 16 of 2011

- Contingencies Fund and County Emergency Funds Act, No. 17 of 2011

- County Governments Act, No. 17 of 2011

- Inter-Governmental Relations Act of 2012

In addressing devolution conflicts, one area that might require attention is human resource vis-à-vis social justice. Why? It is because conflicts of the third world countries look at such in the eyes of ethnicity. In Kenya, National Cohesion Commission came in with further means of de- ethicizing government institutions as well as devolved units. As to whether devolved units are enhancing cohesion or conflict is yet to be determined through a study on the same. Manley (1990) recognizes human resource utilization as the foundation of social justice at its most fundamental level. In a sense to him, underutilization or segregated utilization suffices conflict. 
In other words, making institutions work is a key issue to solving devolution conflicts. Manley (1990) asks, how can these institutions be made a part of the general effort at social reconstruction? To which he answers thus if the same institutions were to work in concert with a government, they could not only accelerate the pace of change required but mobilize people to enthusiastic participation in the process of change, in our case a change to devolution.

A trace of some constitutional phrases on devolution in Kenya out rightly almost at face value shows conflicts when not observed from the spirit and the letter of the constitution. At least in the whole constitution, the Pillars of devolution (Governorship, Senate, and MCA) indicates the change Kenyans took in the new constitutional dispensation yet from different sections of the same constitution, certain portions have been used to cast doubt on whether it was a right decision.

The constitution of Kenya 2010 Art. 1 (4) states that sovereign power of the people is exercised at (a) the national level; and (b) the county level. In lieu of services to the citizens, in Art. $6(1,2, \& 3)$ the constitution highlights the territory as divided into units to make accessibility of services possible to the people. The objects of devolution (Art. 174) according to the constitution can be summed up into the following categories;

- Enhancing democratic governance,

- Recognizing and promoting rights of communities and other interest groups,

- Ensuring equitable sharing of resources, and

- Enhancing checks and balances.

There exist contentions among many stakeholders where cooperation between national and county governments should and as in Art. 189, these are some of the means if meaningfully undertaken can help tackle conflicts. The constitution also provides very good outline on conflict of laws (Art. 191) which when applied appropriately together with other instruments can help mitigations of conflicts.

In enhancing checks and balances, Kobia and Bogaka (2013) suggest, promoting the system of checks and balances in each arm of the government there exists an executive entity, which is in charge of welfare and human resource management functions. The legislature of the national and county governments has the Parliamentary Service Commission (PSC) and the County Assembly Service Board (CASB), respectively.

\subsection{Prospects and Challenges to Devolution and Governance Conflicts in Africa}

African countries including Kenya being cased here have a lot to learn from the Asian experiences of the past. These instances of challenges are imperative in arousing prospects.

In 1976, for the first time, decentralization to the village level namely gram sabha and gram sarkar (local government) was brought into being. In 1982, with the change of the government, gram sarkar was abolished and instead upgradation of Thana into upazila with some powers was done. This means that the decentralization to the village level was curtailed in favour of a higher level namely sub-district level (upazila). Overall, the upazila did not also function well because of weak financial base, stranglehold by the government officials, unrepresentative character of the upazila parishad, and the development of a nexus between the traditional elites and the local administration Barnejee (1997).

In India, the real process of decentralization was started with the establishment of Panchayati Raj in the 1950s. Over time the Panchayat became a three tier system, one at the district, the second at the block and the third at the cluster of village level. The members constituting the different levels were elected. While the intention was excellent, the effectiveness of the system broke down substantially because of delay in (some states, discontinuance of) regular elections, entrenchment of vested interests of the elites in the Panchayats, disassociation of panchayats in many development projects, failure to garner resources, bureaucratic resistance and lack of government will (Muttalib, 1985). Only recently, the central government has made it mandatory of the state governments to have elections at regular intervals. In some states such as West Bengal, the Panchayats have started to function well as a decentralized unit in development work. However, they still are dependent mostly on the resource grants from the state or the centre.

Nepal introduced partyless Panchayati system in 1959. This consisted of a hierarchy of councils from the village to the central level. This is a return to the traditional system of governance ruled by elites. Popular participation was negligible. In 1982, the government enacted the Decentralization Act, which made the District Panchayat as the focal point of development headed by an elected person (Barnejee, 1997)). However, the Act has not made things much different as the government departments continue to act as the major player in most activities.

In Sri Lanka, in 1973, the district administration was restructured with a district political authority. The process of devolution was further improved with district ministership in 1977, the use of decentralized budget in 1974 and establishment of the development councils composed of parliament members, locally elected representatives 
and the local administrators in 1982. However centralism, failure to promote local participation and the politicians' continued attempt to keep the decision making to themselves rather than share with the people have made the attempt to bring about administrative decentralization substantially ineffective (Gunawardena, 1985).

In the Philippines, according to Guzman and Padilla (1985), the decentralized government units below the central government are: barangay, municipality, city, province, and the regional government in the national capital region at Manila and regional autonomous governments in regions IX (Western Mindanao) and XII (Southern Mindanao).

Apart from challenges brought by causes of conflicts in devolution and governance in Africa, the rest of the world has seen challenges like;

- Weak financial bases to devolved systems,

- Stranglehold by government officials and national level,

- Vested interests of the elites,

- Bureaucratic resistance and lack of government will, and

- Negligible popular participation

Despite the drawbacks with devolution world over, Kobia and Bogaka (2013) opine that the devolution experiment in Kenya has brought with it some renewed energy in the management of public affairs. Powers that were originally centralised in one arm of the government have been dispersed to other levels of government and even within arms of the same government these powers have further been dispersed. This dispersal of powers has greatly enhanced the system of checks and balances, and promises to foster democracy in the management of public affairs. While administrative efficiency may not be achieved as fast as one may wish, the democratic values such as accountability, transparency, representation and diversity, among others, promoted through the new public service are worth the cost. In any case, leading and managing changes in public service should be expected and addressed as the two governments enhance service delivery and improve quality of life for the citizens.

A challenge that is reminiscent with the devolution in Kenyan governance structure includes what scholars like Metter; Soss, et'al and Winston in (Omari et 'al, Undated) contend that little is currently known about ramification of the devolution policy making power by an upper level of government where the lower level is only a recipient.

To this challenge it is vital to reinforce as Kotter (2008) state that knowledge on devolution which in essence is transformation from central governance to devolved governance is necessary to facilitate the understanding of counties and know they will be run by the residents, professional's business community, current local government employees and politicians. A central fear among some Kenyans is that from the experience of CDF, decentralization of power in Constituency Development Funds (CDF) has also seen devolution of corruption, nepotism, conflicts and misappropriation of funds (Kiprorir 2008). This thinking forms their skepticism about devolution. However, it is necessary to point that corruption in Kenya though also practiced by low cadre Kenyans; it has been propelled from above. There seems to be no goodwill by some senior government officials who seems to have built a permanent link in successive regimes where there networks never disappear as new governments come.

Though others contend that devolution may intensify inequalities among jurisdiction because some localities are ill-equipped and lack the personnel or policy making capacities necessary to deal with the new authority (Omari et 'al, Undated), it is our view that this thought is ill conceived in the Kenyan case where devolution seems to have neglected even the requirements of National Cohesion Commission for human resource in favour of locals, a direction that looks like taking the devolved units to what would resemble some form of federated states.

A big challenge which is easier said than acted on in the Kenyan polity is what Burugu (2010) cites that national and county governments are expected to work in consultation, exchange of information respect for respective organs institution and structures. It is true this consultation has been broken a thousand times in the short life of Kenya's devolution.

Indeed prospects linger in this new constitutional dispensation in Kenya's history with devolution despite the challenges. As Burugu (2010) indicates, it has indeed opened a new window of change of moving from the central governance to the devolved government.

\section{Conclusion}

The conflicts of devolution and governance in Kenya and Africa at large remain threatening to this system that ideally brings governance closer to people with much sense of participation. Conflicts that the short lived devolution experiences are also found elsewhere and have been experienced in other parts of the globe. 
Mitigations are indeed many but without individuals' resolve and the goodwill of the government of the day not much may be attained. It is our conviction that despite the challenges that surround devolution, the prospects remain enormous. It is our appeal to all stakeholders to guard the system with a crystal clear resolute so that the past governance mistakes become our real guide to bettering Kenya through this system.

\section{Recommendation}

The authors recommend that to deal with long term devolution and governance conflicts in Kenya, a number of suggestions may be embraced. These include;

- The state respecting fundamental principles of socio-eco-political justice,

- Embracing constitutionalism as a panacea to development,

- Developing mechanisms for participation. This also entails real citizen participation being encouraged at the smallest unit of the devolved governance similar to the "barazas" of the former Provincial Administration,

- There should be no feeling of fiscal stress when constitution mandates certain percentage of devolved funds to the counties. In any case, all structures whose existence interfere with pillars of devolution may require re-thinking to ensure devolution works,

- The values enshrined in the National Cohesion should be made practical in the units in order to define a uniform governance culture in all institutions that enhance a feeling of Kenyanism and,

- Devolution is an opportunity for building democratic governance which needs genuine checks and balances for it to root.

\section{References}

Asian Report (2014), Devolution in Pakistan: Reform or Regression? No. 77.

Barnejee, Ajit Kumar (1997), Decentralization and Devolution of Forest Management in Asia and the Pacific, Forestry and Planning Division, Bangkok, Working Paper No. APFSOS/WP/21.

Burugu, N. J. (2010). The County: Understanding Devolution and Governance in Kenya. Nairobi

Colombage, Dinouk (2014), Sri Lanka Says No to Devolution of Powers, Al Jazeera. Constitution of Kenya, 2010.

Daily Nation, 13 September 2013 'Governors accuse official of greed', Back page.

Ghai, Yash Pal (2011) Kenya's Constitution: An Instrument for Change, Clarion, Nairobi

Government of Rwanda: Ministry of Local Government, Good Governance, Community Development and Social Affairs: Decentralization Policy, May 2000, Also see Decentralization Implementation Strategy (2000) and Community Development Policy (2001).

Government of Uganda, Ministry of Local Government, Decentralization Secretariat: Decentralization in Uganda - The policy and its implications (1994).

Gunawardena, Asoka S. (1985), Decentralization, Local government institutions and Resource mobilization - Sri Lanka experience" in 'Decentralization, Local government institutions and Resource Mobilization ed by Hasnat Abdul Hye, BARD. Comilla, Bangladesh.

Guzman, Raul P. de. Guzmanand Perfacto L. Padilla (1985): 'Decentralization, Local government institutions and Resource mobilisation - The Philippines experience in 'Decentralization, Local government institutions and Resource mobilisation ed. by Hasnat Abdul Hye, BARD. Comilla, Bangladesh.

Hye Hasnat Abdul (1985), 'Introduction' in 'Decentralization, Local Government, Institutions and Resource Mobilization' ed. Hasnat Abdul Hye. BARD, Comilla, Bangladesh

Kauzya, John-Mary (2003), "Strengthening Local Governance Capacity for Participation" in Dennis. A. Rondinelli and Shabbir Cheema: Reinventing Government for the Twenty-First Century: State capacity in a Globalizing Society, Kumarian Press, Inc, Bloomfield, CT, USA.

Kauzya, John-Mary (2007), Political Decentralization In Africa: Experiences Of Uganda, Rwanda, And South Africa, a Discussion Paper, New York.

Kennedy, Brian and Bieniek, Lauren (2010) "Moving forward with constitutional reform in Kenya," A Report of the Center for Strategic and International Studies (CSIS), Africa Program, Washington, D.C., www.csis.org/files publication.pdf (accessed 23/9/2010).

Kipkorir, B. E. (2009). Descent from Cherangani Hills; memoirs of a reluctant academic, Macmillan, Kenya

Kobia, M. and Bagaka, Obuya (2013), Separation of powers in Kenya's devolved administrative system: Opportunities and challenges Commonwealth Governance Handbook 2013/14

Kotter, P. J. (2008). A sense of Urgency, Havard Business Press, Boston MA.

Lebrecht, Andy, Finnie MSP, R., Jones AM, C., and Small CB, P. (2002), Evidence to Select Committee on Constitution of House of Lords. 
Manley, Norman (1990), The Politics of Change: A Jamaican Testament. Washington, DC: Howard University Press.

Memorandum by the Scottish Executive, para. 19; evidence volume, p. 110.

Moyo, Ohubani (2014), Devolution is the Way to Go, www.harare24.com 15/06/2014

Mungai, Christine (2013), The new Kenya: How a Complex Devolved System Will Change The Country, The East African, March 162013.

Muttalib M.A. (1985), 'Decentralization: Local self government institutions and Resource mobilisation - The Indian experience" in 'Decentralization, Local government institutions, and Resource mobilisation ed Hasnat Abdul Hye. BARD. Comilla, Bangladesh.

Ndegwa, N (2002), "decentralization in Africa: A Stocktaking Survey" (Africa working Paper Series \# 40, World bank, Washington, D.C.

Omari, A. O., S. N. Kaburi, and T. Sewe (Undated), Change Dilemma: A Case of Structural Adjustment through Devolution in Kenya, A Topical Paper.

Republic of South Africa: Department of Provincial and Local Government: The White Paper on Local Government, 1998.

Sihanya, Ben (2011), Constitutional Implementation in Kenya, 2010-2015: Challenges and Prospects, FES Kenya Occassional Paper, No. 5.

Talbott Kirk and Lynch Owen J. (1995), Balancing Acts: Community-Based Forest Management and National Law in Asia and Pacific. World Resources Institute, Washington D.C.

www.birmingham.ac.uk

\section{About the Authors:}

Thomas Otieno Juma - Lecturer in the Department of History, Political Science, and Public Administration (Moi University); currently pursuing $\mathrm{PhD}$ in International Relations and Diplomacy (IRD) at Nkumba University; MA- IRD (Nkumba University); Holds certificates in Election's Management from International IDEA/UNDP. Has authored a number of books in Diplomacy/Peace/and Politics.

Jacob Kipkemboi Rotich- Lecturer in the Department of Human Resource (Moi University); Currently pursuing PhD in Human Resource Development at Moi University; Holds MSc- HR (Moi University); Has authored a book on Strategic Management and Public Administration.

Prof. Leonard Simiyu Mulongo (PhD)- An Associate Professor of Development Studies in Moi University; Currently is a Lead Consultant in Environmental Assessment and Audit in Kenya; Has authored a number of books and articles in refereed journals. 
The IISTE is a pioneer in the Open-Access hosting service and academic event management. The aim of the firm is Accelerating Global Knowledge Sharing.

More information about the firm can be found on the homepage:

http://www.iiste.org

\section{CALL FOR JOURNAL PAPERS}

There are more than 30 peer-reviewed academic journals hosted under the hosting platform.

Prospective authors of journals can find the submission instruction on the following page: http://www.iiste.org/journals/ All the journals articles are available online to the readers all over the world without financial, legal, or technical barriers other than those inseparable from gaining access to the internet itself. Paper version of the journals is also available upon request of readers and authors.

\section{MORE RESOURCES}

Book publication information: http://www.iiste.org/book/

\section{IISTE Knowledge Sharing Partners}

EBSCO, Index Copernicus, Ulrich's Periodicals Directory, JournalTOCS, PKP Open Archives Harvester, Bielefeld Academic Search Engine, Elektronische Zeitschriftenbibliothek EZB, Open J-Gate, OCLC WorldCat, Universe Digtial Library, NewJour, Google Scholar

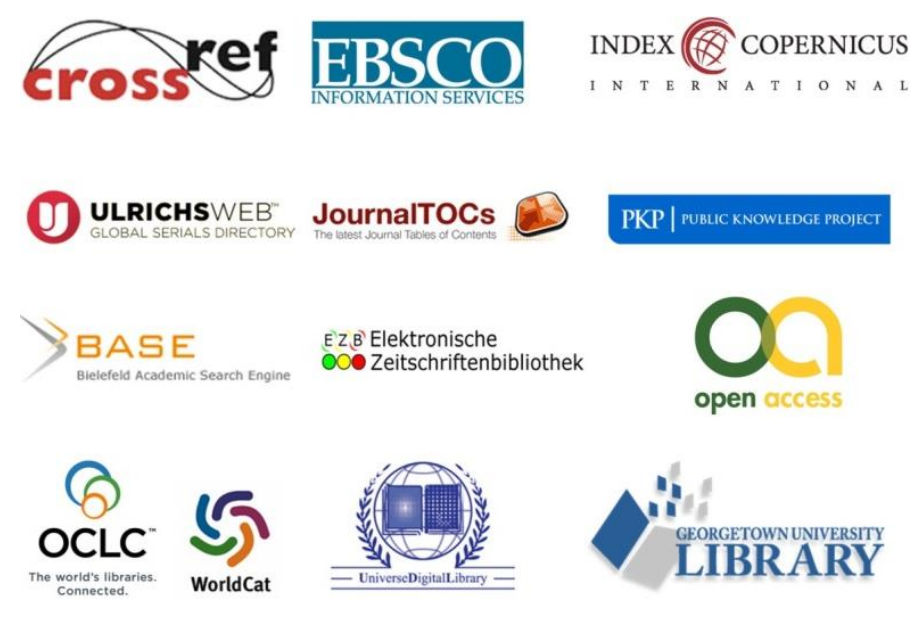

